NBER WORKING PAPER SERIES

\title{
WHAT IS THE IMPACT OF SOFTWARE PATENT SHIFTS?: EVIDENCE FROM LOTUS V. BORLAND
}

\author{
Josh Lerner \\ Feng Zhu \\ Working Paper 11168 \\ http://www.nber.org/papers/w11168 \\ NATIONAL BUREAU OF ECONOMIC RESEARCH \\ 1050 Massachusetts Avenue \\ Cambridge, MA 02138 \\ March 2005
}

Harvard Business School's Division of Research provided financial support. We thank Iain Cockburn, David Evans, Neil Gandal, Anne Layne-Farrar, Marc Rysman, and Mark Schankerman for helpful comments, seminar audiences at Harvard and Toulouse, as well as LECG for access to the LECG software database. All errors are our own. The views expressed herein are those of the author(s) and do not necessarily reflect the views of the National Bureau of Economic Research.

(C) 2005 by Josh Lerner and Feng Zhu. All rights reserved. Short sections of text, not to exceed two paragraphs, may be quoted without explicit permission provided that full credit, including $\odot$ notice, is given to the source. 
What is the Impact of Software Patent Shifts?: Evidence from Lotus v. Borland Josh Lerner and Feng Zhu

NBER Working Paper No. 11168

March 2005

JEL No. O3

\begin{abstract}
$\underline{\text { ABSTRACT }}$
Economists have debated the extent to which strengthening patent protection spurs or detracts from technological innovation. In this paper, we examine the reduction of software copyright protection in the Lotus v. Borland decision. If patent and copyright protections are substitutes, then weakening of one form of protection should be associated with an increasing reliance on the other. We find that the firms affected by the diminution of copyright protection disproportionately accelerated their patenting in subsequent years. But little evidence can be found for harmful effects: in fact, the increased reliance on patents is correlated with some positive outcomes for firms.
\end{abstract}

Josh Lerner

Harvard Business School

Morgan Hall, Room 395

Cambridge, MA 02163

and NBER

josh@hbs.edu

Feng Zhu

Harvard Business School

Sherman Hall

Cambridge, MA 02163

fzhu@hbs.edu 


\section{Introduction}

One of the most enduring questions in the literature on the economics of technological change relates to the impact of patent protection. Economists have hotly debated the extent to which allowing strong patent rights spurs or detracts from technological innovation.

In recent years, a particular hotbed for these discussions has related to the impact of patents in emerging industries. A substantial literature on incomplete contracting, beginning with Grossman and Hart [1986] and Hart and Moore [1990], suggests that firms will be unwilling to invest when risks of expropriation are high. A number of critics have charged that these problems are particularly intense in regard to patents: both academic and practitioners have asserted that the poor quality of patent reviews has created a "thicket" of overlapping patent holdings that make these expropriation problems likely. In particular, by granting large number of property rights on small blocks of technology, patent office officials may make it difficult for firms to access the critical intellectual properties they need (see, for instance, Heller and Eisenberg [1998], Shapiro [2001], and Ziedonis [2004]). As a result, firms will have reduced incentives to innovate.

This paper examines these issues by studying the software industry. Patents have been intensely controversial in this industry, largely for the reasons delineated above. The limited work to date that has made these arguments, especially Bessen and Hunt [2004], is frequently cited by policymakers: see, for instance, the 2003 debate about 
software patents in the European Parliament. Other scholars, however, have disputed these claims (see, for example, Mann [2004]). But to date, the claims regarding impact of patenting on the development of the software industry have received little empirical evaluation.

This paper is related to earlier empirical works, which have largely focused on understanding the impacts of a single intellectual property policy reform. Examples include studies of the broadening of Japanese patent scope (Sakakibara and Branstetter [2001]), the establishment of the Court of Appeals for the Federal Circuit in the United States (Kortum and Lerner [1998], Hall and Ziedonis [2001]), and the strengthening of patent protection of pharmaceuticals in such nations as India (Lanjouw [1998]) and Italy (Scherer and Weisburst [1995]).

Somewhat unlike these studies, however, we focus on a change that involved an alternative form of intellectual property protection: the reduction of software copyright protection in the Lotus $v$. Borland decision. If patent and copyright protections are substitutes, then the weakening of one form of protection should be associated with an increasing reliance on the other. ${ }^{1}$ We rely on this methodology because there is no single event that unambiguously established the patentability of software, while this had the

\footnotetext{
${ }^{1}$ The view that patents and copyrights are substitutes has emerged from a considerable number of legal and economic analyses of these questions that have been informed by practitioner discussions, including Menell [1989], Lemley and O'Brien [1997], and Mowery and Graham [2003]. It is still possible, however, that patents and copyrights are not substitutes. Therefore, their relationship is part of what we are testing when we examine empirically the impact of the judicial decisions concerning copyright on the level of patent filings.
} 
clear earmarks of a shock to the system. We examine if the increased reliance on patents after this decision led to a decrease in innovation for the reasons spelled out by the critics.

In this analysis, we undertake a "differences-in-differences" analysis. We examine the subset of firms that were most effected by the decision in Lotus v. Borland as determined through an event study around the announcement of the judicial decision, which we subsequently refer to as "interface firms." ${ }^{2}$ (The results are also robust to identifying the firms through a subjective classification of which firms were likely to be affected.) We compare the shifts in the behavior of these firms with other software firms, which should have been less affected by the increased reliance of patenting.

We find that the judicial decision appears to have had a considerable impact on patenting. The number of patent applications filed appears to have increased more dramatically for the interface firms than the others. But little evidence can be found for any harmful effects from this policy shift. In fact, the increased reliance on patent protection appears to be correlated with significant growth in a number of performance measures such as sales levels.

This finding must, of course, be interpreted with caution. Our division between the affected and unaffected firms is somewhat crude. The environment is a complex one: many other changes, such as the widespread dissemination of the Internet, may have

\footnotetext{
${ }^{2}$ The Lotus v. Borland case concerns the copyrightability of software interfaces. Therefore, we expect that the firms most affected by the judicial decisions develop software in which interfaces are the key elements.
} 
differentially affected firms during this period. Finally, the affects of the patent thicket problems may take longer to be felt than examined here.

The outline of this paper is as follows. Section 2 briefly reviews the history of intellectual property protection in the U.S. software industry. Section 3 described the construction of the dataset. Section 4 presents the analysis. The final section concludes the paper.

\section{Intellectual Property Protection of Software in the United States}

The USPTO traditionally was reluctant to grant patents on computer software inventions. Through the 1970s, the Office resisted granting such patents on the grounds that computer programs were mathematical algorithms, and not in the categories allowed by Section 101 of the U.S. Patent Act: processes, machines, articles of manufacture, and compositions of matter.

The USPTO changed its position after a series of U.S. Supreme Court decisions. In the 1981 case Diamond $v$. Diehr, the Court ordered the USPTO to grant a patent on an invention involving computer software that determining how rubber should be heated as

part of the curing process. The Court stated that because the invention was not merely a mathematical algorithm, but also included steps for processing the rubber, the patent was valid. 
This decision, and the ones by the Supreme Court that followed (such as Diamond v. Bradley, 1981), led to considerable confusion. Despite the best efforts of lower courts to clarify the decisions, patentees struggled to determine when an invention was merely a mathematical algorithm, and when it was in fact a patentable invention that simply contained a mathematical algorithm.

In 1995, the USPTO decided it was time to develop guidelines for patent examiners that reflect these recent court decisions. In its Final Computer Related Examination Guidelines, it opened the door to the patentability of most software related inventions are now statutory under these guidelines. In particular, it created "safe harbor" exemptions for inventions having "significant post solution activity", meaning that the software program is used to control something external to the software program, or "precomputer process activity", meaning software programs that manipulate numbers representing concrete, real world values. Also, software can be patented if it is claimed in connection with a specific machine or product, including such diverse inventions as a graphics program, a spreadsheet, and a word processing program. Many observers suggested that these guidelines only codified a change that had already been already put into practice.

Meanwhile, the feasibility of copyrights on computer software had been first been suggested by the major reform of the copyright system in 1976. The act had left ambiguous, however, many of the details about such protection. Through the 1980 
amendment to the copyright act, Congress finally gave a statutory basis to copyright protection for software, but important ambiguities still remained.

The most important of these related to the scope of copyright protection. The courts had long recognized a distinction between copyrights, which protects expression, and patents, which protect useful procedures or machines. To what extent did the protection for software extend beyond the actual code?

Three decisions in the ensuing dozen years highlighted this confusion. In the 1986 case, Whelan v. Jaslow, concerned a dental laboratory management software system, which a dentist had hired a programmer to write for his minicomputer in the EDL language. After a few years, the programmer wrote a similar program for personal computers in BASIC. The dentist sued for copyright infringement, even through the new program was in a different language and differed in some respects. The court, pointing to the similar interfaces used by the new program, argued that it was too close to the original program, and thus violated its copyright.

In the 1990 case, Lotus v. Paperback Software and Mosaic Software, the curt again decided in favor of a plaintiff in an infringement case. Paperback and Mosaic had both came out with spreadsheet pro grams that displayed extreme similarities to Lotus's 1-2-3. In the decision, the court basically determined that a company has the right to copyright the "look and feel" of its user interface. 
The logic in these decisions was sharply criticized in the 1991 decision in Computer Associates v. Altai. In this decision, the court found in favor of the alleged copyright infringer, referring to the precedent in the earlier cases as "inadequate and inaccurate." In particular, the judge cast doubt on the proposition that the structure of the program or its interfaces could be used to determine whether a program was infringing.

It was against this backdrop that the case between Lotus and Borland was heard. Lotus argued that Borland had copied key aspects of its 1-2-3 spreadsheet for the Quattro programs, including menu commands and structure, long prompts, keystroke sequences, and macro language. At the district level, the court in July 1992 made a summary judgment ruling for Lotus, arguing the Quattro program was similar enough to infringe on the copyright for the 1-2-3 interface. Borland appealed to the appellate court for the first circuit, which in March 1995 reversed the decision, holding "that the Lotus menu command hierarchy is uncopyrightable subject matter," because it was little more than a "method of operation." Ten months later, this decision was upheld by an equally divided Supreme Court. While the split in the court meant that the decision did not bind beyond the first circuit, the decisions attracted a great of protection and were perceived as signaling a sharp limitation of the scope of copyright protection.

Thus, the treatment of patenting software changed only gradually over this period. It seems hard to identify a single event or shock that shifted perceptions. The value of copyrights for protecting software, however, was dramatically revised downward as a means of protecting computer interfaces after the Lotus v. Borland decision. If these two 
forms of intellectual property protection were substitutes, the affected firms should have increasingly relied on patent protection after the decision.

Although the Computer Associates v. Altai ruling in 1991 might have influenced the affected firms' patenting behaviors, its effect was compounded by the 1992 Lotus $v$. Borland ruling by the district court, in which the Lotus 1-2-3 interface was determined to be copyrightable. The district court ruling also implies that the Altai ruling did not set much of a precedent for copyrightability of software interfaces. It was the 1996 Supreme Court ruling of the Lotus v. Borland case that made the copyrightability of software interfaces abundantly clear. As the 1996 ruling had the clear earmarks of a shock to the system, our analysis below will focus on this policy shift.

\section{The Data}

The primary data for the LECG software database, which this analysis employs, was purchased from Corporate Technology Information Services (CorpTech). This data was supplemented with variables from Compustat, the Center for Research into Securities Prices (CRSP) database, Venture Economics' VentureXpert (formerly known as Venture Intelligence) Database, and the USPTO's Patent database.

CorpTech was founded in 1986 to prepare an annual directory and customized databases for high technology firms in the United States. In 2000, it was acquired by OneSource, and has been its subsidiary since then. CorpTech is a unique source of information available on 50,000 U.S. high technology manufacturing companies in 18 
industries. Its data covers public and private companies (information that is not accessible through any other sources) and includes large companies, new companies, emerging companies, and subsidiaries and operating units of U.S. and foreign companies. ${ }^{3}$

In all, we have 51,420 observations on 15,207 software companies for 19902002. ${ }^{4}$ The data are available every other year for even years: 1990, 1992, 1994, 1996, 1998, 2000 and 2002. Approximately 12\% of our sample are firms that were publicly traded companies for all or some of the sample period. For these firms, we have added CUSIPs, allowing the data to be matched to Compustat and CRSP data. We encountered a few issues while adding CUSIP information to public companies. First, many companies in our dataset are subsidiaries. We added CUSIP information of a parent company for such companies. All information merged by CUSIP variable, such as Compustat data, reflects the parent company's information. Second, we could not locate CUSIP information for about 12 percent of all public companies in our dataset—some companies had ceased their operations, some companies became private, and others simply could not be located. Note that some of the firms that report themselves as public in CorpTech are traded on the pink sheets or overseas, and thus are not picked up by Compustat and CRSP.

\footnotetext{
${ }^{3}$ See CorpTech website at < http://www.corptech.com/business-information/methodology.php $>$.

${ }^{4} \mathrm{We}$ define software companies as those that have at least one detailed product classification beginning with "SOF." That is, to be included in our dataset, the firm had to consider software development as an intentional part of its business, thus listing the category of software it develops when interviewed by CorpTech. This definition excludes some firms that patent software but do not consider themselves software companies, such as Hewlett Packard. Subsidiaries of Hewlett Packard (and other such companies) are included if they listed at least one software development category ("SOF").
} 
From patent data purchased from the U.S. Patent and Trademark Office, we identified all software patents. We included all patents classified under International Classification (IPC) G06F and granted between 1976 and 2000 - a total of 76,920 patents. We merged these files using the name and location of the assignee in the USPTO database, as well as the subject of the award. In total we obtained 24,006 patent-tocompany matches. The unmatched patents were largely awarded to individuals and foreign corporations.

The process of matching the VentureXpert data proceeded similarly, exploiting the detailed name, location and business line information compiled by Venture Economics.

Table 1 summarizes the sample along several key dimensions of firm performance. The number of patent filings is that in the current and previous year-e.g., for 2000, the tabulation includes filings made in 1999 and 2000 - while for the other measures, the revenues and the employment at the end of the year are tabulated. The compilation of successful patent applications only includes patents awarded as of mid2003. Thus, the compilation for 2000 is sharply lower than the others, not because fewer flings had been made, but because few of those filed in this period had yet issued. Little time trend is apparent: this reflects the fact that while many of the established firms grew rapidly over this period, there was also considerably entry of small new firms.

\section{The Analysis}


We now proceed to analyze the patterns seen in the data. We first discuss the way in which we classify the observations into the group that are and are not likely to be affected by the Lotus v. Borland decision. We then present the results regarding patenting and other indicators of firm success. Finally, we discuss the robustness of the results.

\section{A. Classifying the Firms}

A central challenge here is to separate the firms into those likely to be affected by the copyright decision and not. There was no one, obvious approach to addressing this issue. We thus took a variety of approaches.

Our preferred approach was the most objective: to look at the types of firms most affected by these decisions. To implement this, we looked at the subset of publicly traded software firms around the time of the three judicial decisions in the Lotus $v$. Borland case. ${ }^{5}$ We estimated an event study, where one observation was used for each firm and each judicial decision. The dependent variable was the actual return of the firm in a window around the event. As independent variables, we employ dummy variables denoting the 359 distinct technology classes into which the firms were sorted, as well as dummy variables for each observation date. The industry dummy variables are coded as one if the firm was assigned to that class based on the 1994 classification scheme when

\footnotetext{
${ }^{5}$ The three judicial decisions are: 1) on July 31,1992 , the district court ruled that the Lotus menu command hierarchy was copyrightable expression and Borland had illegally copied large parts of the Lotus 1-2-3 command structure; 2) on March 9, 1995, the 1st US Circuit Court of Appeals reversed the 1992 ruling and determined that Lotus' menu structures, incorporated into Borland's Quatro Pro spreadsheet, are "an uncopyrightable method of operation"; and 3) on January 16, 1996 the Supreme Court upholds the ruling, thus affirming the decision by the appeal court.
} 
such scheme is recorded by Corptech or the classification scheme in the closest year to 1994.

We alternatively use the absolute return of the firm and the actual return as a dependent variable. In the case of the actual return, as the decision on the district level was favorable to copyright holders, we negate the actual return in the window around that event. If we wish to identify the firms most adversely affected by the decisions, we should look at the ones who have the most persistently negative reaction. These should be the firms that relied most heavily on copyright protection. But this view is a little problematic: after all, our dataset contains both copyright holders and copyright infringers. A judicial decision that is unfavorable to one group would be favorable to the other. A better approach is to examine the absolute returns. The firms that moved the most in response to the decisions, whether in a positive or negative manner, may be the most appropriate ones to employ.

We use different event windows to reflect possible delays in incorporating the information into the stock price. While the judicial decisions have a clear timing, there may be lags associated with understanding the implications of the decisions for particular firms. We thus use windows from one day before to one day after up to three days before to three days after.

We then examine the coefficients on the technology classes based on the regressions. If the coefficient takes on the expected sign and is significant at the .2 level 
in a two-sided, we define this as a "strongly" affected class. If the coefficient takes on the expected sign but is significant at a lower level, we define this as a "medium" class. Otherwise, we regard it as unaffected. We then assign all firms-whether public or private-in the strong class or alternatively in the strong and medium class to be the ones we anticipate being affected by the decision.

An alternative approach is to rely on industry knowledge to classify the firms. We also undertake an a priori classification, assigning firms in a variety of technology classes to be likely to be affected by the decision. These are categories where we believe interfaces to be particularly important: accounting, banking, education, file management, financial analysis, health services, and insurance.

Table 2 summarizes the different classification schemes employed. It indicates for each approach the number of firms assigned to the strong and medium groups. We also compare the distribution to that in the scheme we ultimately relied on for the base analysis: using the absolute returns and the window from two days before to two days after the decision. One encouraging aspect is the considerable degree of overlap across the different schemes: in each case, including our a priori classification, we are disproportionately choosing the same firms as the affected ones. In the following analysis, we consider those firms who are assigned to the strong or median groups as interface firms.

\section{B. Impact on Patenting and Firm Growth}


We now proceed to understand the impact of the shift on patenting and measures of firm performance. The patenting analysis can be understood as a validation exercise for our selection process. If there is no increase in relative number patent applications filed for the group presumably affected by the Lotus $v$. Borland decision, we must worry that our identification of these firms is problematic or that our claim that patents and copyrights are substitutes is problematic. We then focus on firm performance. If the arguments outlined in the introduction are valid, we should see detrimental effects from the increasing reliance on patent protection.

Figure 1 displays the basic pattern regard to patenting. The number of patent applications filed by interface firms exceeds that by non-interface firms after 1992. In particular, beginning with 1995-96 there seems to be a substantial increase in the rate of patenting.

Table 3 presents similar before and after data for seven indicators of firm performance: sales, total assets, market capitalization, the number of employees, sales per employee, R\&D expenditure and the number of product lines. In the case of sales and employees, as well as the ratio, we have data on the majority of the firms in the CorpTech database. In the case of the others, we have data only for the much smaller subset of firms that are in Compustat. The table presents the mean, median and standard deviation of each performance indicator for interface firms and non-interface firms respectively. We observe that the growth rate for interface firms is greater than the one for noninterface firms in several cases such as sales in 1996 and 1998, and number of employees 
in 1996. Interestingly, interface firms have been expanding their product lines more rapidly than non-interface firms in all even years between 1990 and 1998.

We then turn to examining these patterns in a regression framework. We first examine the impact of the Lotus v. Borland ruling on patenting. We undertake a "difference-in-difference" approach to compare the differences in patenting activities before and after the policy shift for those affected and those not. Table 4 presents the results from three different regression specifications: Poisson, OLS and Negative Binomial. For the Poisson and Negative Binomial specifications, the number of patents filed in the current and previous year is used as the dependent variable. For the OLS specification, the natural logarithm of (the number of patents filed in the current and previous year +1 ) is used as the dependent variable. Year dummies, the dummy for interface firm and the interaction terms between interface firm and year dummies are used as explanatory variables.

As the observed difference in patenting activities may result from underlying shifts in firm-level or industry-level characteristics rather than the policy shift, we need to control for these characteristics. We thus include firm-level controls such as the age of the firm, lagged value of the sales and the lagged total number of patents filed. ${ }^{6}$

Entry rate in each technology class is also used to control for industry-level competition, as firms may rely more heavily on patents to gain competitive advantages as

\footnotetext{
${ }^{6}$ In all our regression analyses, lagged values for year $\mathrm{t}$ are referring to the values in year $\mathrm{t}-2$ (reflecting the fact we have observations on a biannual basis).
} 
the industry becomes more competitive. The entry rate is calculated as the ratio between the number of new entries in a technology class and the total number of firms in that class. For firms that have multiple lines of business, we use the average of the entry rate in each technology class that the firms have been sorted into. It is possible that some firms in a technology class are not recorded by CorpTech. Those firms are most likely small ones so that they were not on CorpTech's radar screen. Thus the presence of those firms would not have a large impact on the competitive environment.

As we do not have any observations before year 1990, we are not able to compute the entry rates in year 1990. Therefore, in our analysis we exclude year 1990. Also as our dataset only contains very few patent applications filed between 1999 and 2000, we exclude year 2000 in our analysis. ${ }^{7}$

The results in Table 4 are consistent with the hypothesis that the reduction in the copyright protection leads to more patenting, as evidenced by the significantly positive coefficients for the interaction terms between the interface dummy and year dummies. Our results also indicate several things. First, given everything else equal, interface firms tend to file fewer patents than non-interface firms on average. Second, firms tend to patent more if they have filed many patent applications in the past. Finally, a more competitive environment tends to motivate firms to file more patent applications.

\footnotetext{
${ }^{7}$ In addition, we are concerned that the State Street case (resolved by the Supreme Court in 1999) may have increased the number of financial patents and thus made the regression results difficult to interpret.
} 
We now proceed to examine the impact of patenting activities on firms' performance. The correlation between a firm's patenting activity and its performance is difficult to examine directly as both of them may be caused by third factors such as the size of the firm. The Lotus v. Borland decision presents an exogenous shock and thus enables us to employ the instrumental estimator to address this endogeneity problem. Table 5 reports the results. The regressions presented in Table 4 are used as the first stage. In the second stage, we use the predicted number of patents from the first stage as an instrumented variable. In Table 5, the predicted number of patents is derived from the full-model Poisson specification in Table 4.

For dependent variables, we use the growth rates of seven measures: sales, total asset, market capitalizations, employment, sales per employee, R\&D expenditure and number of lines of business. As above, each observation of a firm at a two-year interval is used as an independent observation.

We first estimate the growth measures without using the patenting variable. The idea here is to examine whether firms in sectors with more generous patent policies grow more rapidly, regardless of their specific patenting activity. Then we add the lagged predicted number of patents and its interaction with interface and year dummies to examine to what extent the difference in their patenting activity affects their financial performance. As control variables, we first employ the lagged value of each growth measure: for instance, the level of sales at the beginning of the two-year interval if the growth rate of sales is used as the dependent variable. We also include entry rate and the 
age of the firm. An OLS specification is used for all regressions. We then repeat the above procedures for the inception of venture financing. A probit model is employed here.

As reported in Table 5, we find little evidence that more generous or restrictive patent policies significantly affect the growth rates of the firms: in almost all regressions without the predicted patenting variable, no significant differences between interface and non-interface firms are detected. Only in the cases of sales growth in 1996 and employment growth in 1998, we observe significant declines for interface firms. We do not have a ready explanation for these declines. The result for product line expansion is consistent with our early observation that interface firms in general are more active in expanding their business lines.

Once we control for firm patenting behavior, we find no evidence for any harmful effects from the judicial decision: none of the growth measures and the inception of venture financing seem negatively affected by this policy shift. In fact, we find that the increased reliance on patent protection is correlated with significant growth in sales and business lines in 1996 and 1998, and number of employees, market capitalization and sales per employee in 1998. We also note that the increased reliance on patenting did not appear to lead to any decrease in innovation, as evidenced by the regression result where $\mathrm{R} \& \mathrm{D}$ growth is used as the dependent variable.

\section{Exploring Robustness}


A natural concern is whether the results above or are a consequence of the way in which the firms were identified or of confounding event. We thus repeat the analysis in several ways to explore the robustness of the finding.

Table 6 summarizes one of these robustness analyses. Rather than relying on a single definition of what constitutes firms likely to be affected by the Lotus v. Borland decision, we rely on alternative rules to identify these firms. In particular, as in Table 2 , we rely on different event windows and relative rather than absolute returns for identifying affected firms. The table replicates some the analyses reported in Table 4, showing that the same patterns appear with the alternative definitions. In unreported regressions, we show that using the other alternative definitions in Table 2 have little impact on the patenting results, and that the results replicating the analyses in Table 5 are similar.

In our analysis, a firm is considered as an interface firm if it has one or more business lines in the affected group. This scheme would include firms as interface firms even if they only have a small portion of business lines in the affected group. In an unreported analysis, we repeat our analyses in Table 4 and 5 using a new classification scheme in which a firm is considered affected only if it has more than 50 percent of its business lines in the affected group. We compared these firms to the ones that have no business lines in the affected group. The results are similar to those in Tables 4 and 5. 
We were also concerned about different user groups these software firms target. In particular, software firms can develop software for enterprises or home users. The policy shift may affect these two groups differently if one group cares more about intellectual property protection than the other. To address this concern, we repeat the analyses, after eliminating all firms whose products run on mainframe computers. The results are similar except that when we replicate the analysis in Table 4, the coefficients of the interaction terms, (interface * year 1996) and (interface * year 1998), more than double in all specifications. This suggests that firms targeting at enterprises are less responsive to the judicial decision, possibly due to the fact that interface design is not the most important element of their products and they are less affected by the policy shift as a result.

Our fourth concern was whether the results were shaped by confounding events. In particular, was there an event that may have affected interface firms different from other corporations? We explore the most visible candidate: the widespread diffusion of access to the World Wide Web in the mid-1990s. While it is not obvious that interface firms would be more affected, this possibility is worrisome. To address this concern, we repeat the analyses in Tables 4 and 5, now eliminating all firms geared towards the Internet (we identify these by eliminating firms that develops products based on Web browsers or have Java as a key software platform.) We obtain similar results.

\section{Conclusions}


The growth of software patenting has triggered numerous concerns among academics, practitioners and policymakers. In particular, the diversity of the patent holdings in this area, and the alleged failure of the patent awards to always reward true innovators, have led to concerns of expropriation problems for innovators. These claims, however, have been little scrutinized empirically.

In this paper, we focus on the reduction of software copyright protection in the Lotus v. Borland decision. If patent and copyright protections are substitutes, then the weakening of one form of protection should be associated with an increasing reliance on the other. We rely on this methodology because there is no single event that unambiguously established the patentability of software, while this had the clear earmarks of a shock to the system.

We examine the subset of firms that were most affected by the decision in Lotus v. Borland, as determined through an event study around the announcement of the judicial decision, and compare the shifts in the behavior of these firms with other software firms, which should have been less affected by the decreased effectiveness of copyright. We find that the judicial decision appears to have had a considerable impact on patenting. The number of patent applications filed appears to have increased more dramatically for the interface firms than the others. But little evidence can be found for any harmful effects from this policy shift. In fact, the increased reliance on patent protection appears to be correlated with significant growth in a number of performance measures such as the level of sales. While our interpretation must be cautious, we 
conclude there is little evidence of harm from the increased reliance on software patenting. 


\section{References}

Bessen, James, and Robert M. Hunt, 2004, “An Empirical Look at Software Patents," Federal Reserve Bank of Philadelphia Working Paper 03-17/R.

Grossman, Sanford J., and Oliver D. Hart, 1986, "The Costs and Benefits of Ownership: A Theory of Vertical and Lateral Integration," Journal of Political Economy. 94, 691719.

Hall, Bronwyn H., and Rosemarie H. Ziedonis, 2001, "The Patent Paradox Revisited: An Empirical Study of Patenting in the U.S. Semiconductor Industry, 1979-1995," Rand Journal of Economics. 32, 101-128.

Hart, Oliver, and John Moore, 1990, "Property Rights and the Nature of the Firm," Journal of Political Economy. 98, 1119-1158.

Heller, Michael A. and Rebecca S. Eisenberg, 1998, "Can Patents Deter Innovation? The Anticommons in Biomedical Research," Science. 280, 698-701.

Kortum, Samuel, and Josh Lerner, 1998, "Stronger Protection or Technological Revolution: What is Behind the Recent Surge in Patenting?," Carnegie-Rochester Conference Series on Public Policy. 48, 247-304.

Lanjouw, Jean O., 1998, “The Introduction of Pharmaceutical product Patents in India: 'Heartless Exploitation of the Poor and Suffering'?,' Working Paper No. 6366, National Bureau of Economic Research.

Lemley, Mark, and David O'Brien, 1997, "Encouraging Software Reuse," Stanford Law Review, 49, 255-305.

Mann, Ronald J., 2004, "Do Patents Facilitate Financing in the Software Industry?" University of Texas Law and Economics Research Paper.

Menell, Peter S., 1989, "An Analysis of the Scope of Copyright Protection for Computer Programs," Stanford Law Review, 41, 1045-1104.

Mowery, David, and Stuart Graham, 2003, "Intellectual Property Protection in the U.S. Software Industry," in Wesley Cohen and Steven Merrill, editor, Patents in the Knowledge-based Economy: Proceedings of the Science, Technology and Economic Policy Board, National Academies Press.

Sakakibara, Mariko, and Lee Branstetter, 2001, "Do Stronger Patents Induce More Innovation? Evidence from the 1988 Japanese Patent Law Reforms," Rand Journal of Economics. 32, 77-10. 
Scherer, F.M., and Sanford Weisburst, 1995, "Economic Effects of Strengthening Pharmaceutical Patent Protection in Italy," International Review of Industrial Property and Copyright Law. 6, 1009-1024.

Shapiro, Carl, 2001, "Navigating the Patent Thickets: Cross-Licenses, Patent Pools, and Standard-Setting," in Adam B. Jaffe, Josh Lerner, and Scott Stern, editor, Innovation Policy and the Economy, volume 1, Cambridge Massachusetts, National Bureau of Economic Research.

Ziedonis, Rosemarie H., 2004, “Don't Fence Me In: Fragmented Markets for Technology and the Patent Acquisition Strategies of Firms," Management Science. 50, 804-82. 


\section{Figure 1}

Patenting behaviors by interface firms and non-interface firms. We compute the average number of patents filed by interface and non-interface firms each year. Note that as we only consider even years between 1990 and 2000, the number of patents filed in year $t$ is the sum of patents filed in year $t$ and year $t-1$. The number of patent applications filed in year 2000 is very low due to truncation: many patents filed in that year have not issued.

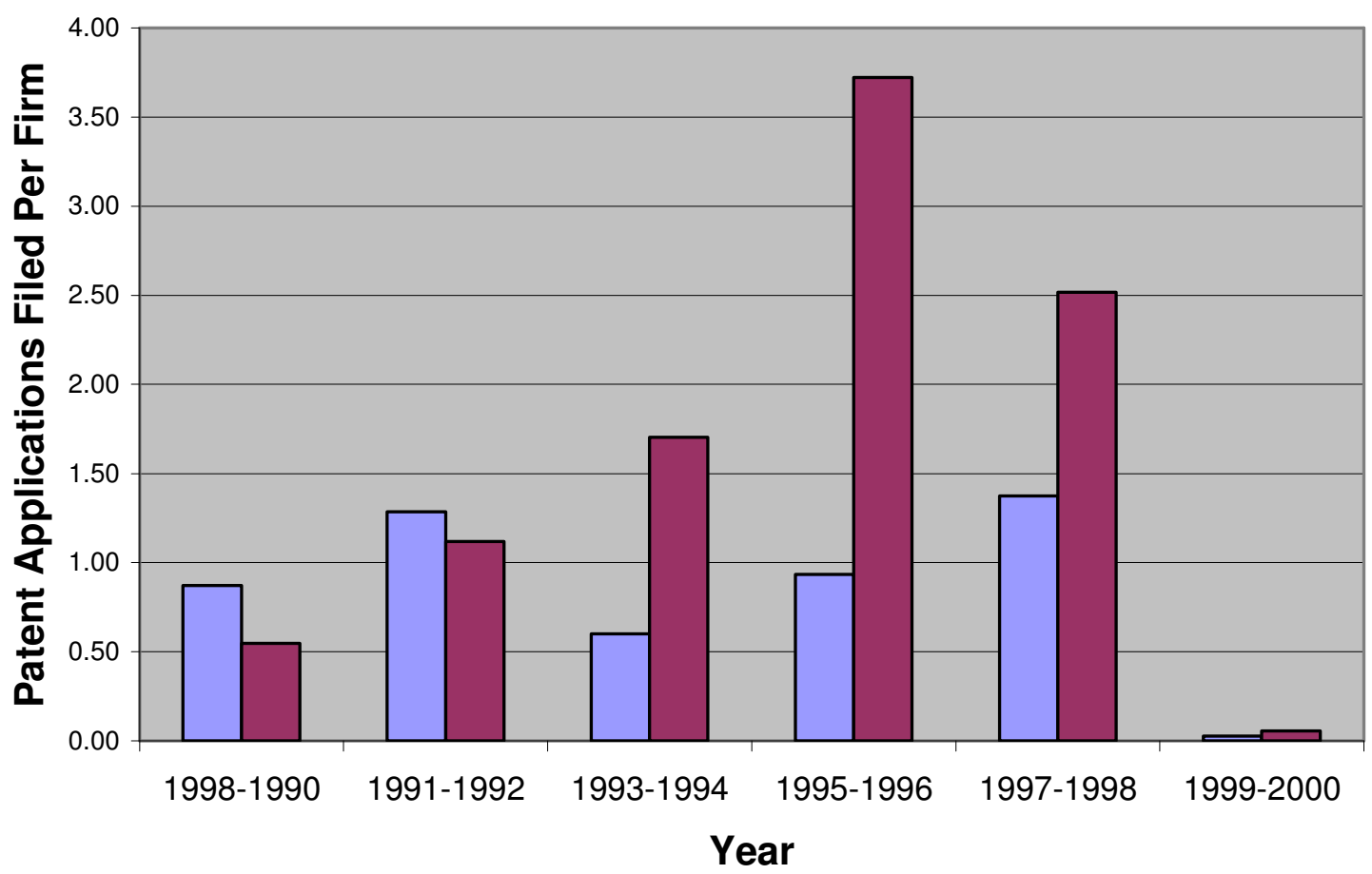

$\square$ Non-Interface Firms $\quad \square$ Interface Firms 


\section{Table 1}

Some characteristics of the sample. Panel A reports summary statistics for the number of patents filed by year. Panel B reports sales statistics by year. Panel C reports summary statistics for the number of employees in each firm by year.

\begin{tabular}{|c|c|c|c|c|}
\hline \multicolumn{5}{|c|}{$\begin{array}{c}\text { Panel A: Number of Patent Applications Filed by Each Firm in This and } \\
\text { Previous Year }\end{array}$} \\
\hline Year & Mean & Std. Deviation & Minimum & Maximum \\
\hline 1990 & .64 & 14.98 & 0 & 556 \\
\hline 1992 & 1.17 & 27.79 & 0 & 962 \\
\hline 1994 & 1.34 & 31.97 & 0 & 1192 \\
\hline 1996 & 2.78 & 63.66 & 0 & 2165 \\
\hline 1998 & 2.12 & 5.99 & 0 & 1885 \\
\hline 2000 & .04 & .94 & 0 & 34 \\
\hline Total & 1.29 & 38.61 & 0 & 2165 \\
\hline
\end{tabular}

Panel B: Sales in Year (Million dollars)

\begin{tabular}{ccccc}
\hline Year & Mean & Std. Deviation & Minimum & Maximum \\
1990 & 133.62 & 2496.52 & 0 & 89583.3 \\
1992 & 123.96 & 2618.94 & 0 & 86846.68 \\
1994 & 81.36 & 1757.36 & 0 & 94083.89 \\
1996 & 110.59 & 1942.37 & 0 & 89515.8 \\
1998 & 115.77 & 1140.54 & 0 & 50954.43 \\
2000 & 98.66 & 1508.38 & -.34 & 87500 \\
Total & $\mathbf{1 0 4 . 5 0}$ & $\mathbf{1 8 4 1 . 8 6}$ & $\mathbf{- . 3 4}$ & $\mathbf{9 4 0 8 3 . 8 9}$
\end{tabular}

Panel C: Number of Employees in Each Firm at End of Year

\begin{tabular}{ccccc}
\hline Year & Mean & Std. Deviation & Minimum & Maximum \\
1990 & 217.14 & 3789.06 & 1 & 127927 \\
1992 & 346.66 & 6988.45 & 1 & 317100 \\
1994 & 161.50 & 1266.30 & 1 & 50000 \\
1996 & 215.62 & 4623.19 & 1 & 295000 \\
1998 & 265.68 & 2997.68 & 1 & 121000 \\
2000 & 406.24 & 5167.87 & 1 & 307401 \\
Total & $\mathbf{2 9 7 . 3 1 2}$ & $\mathbf{4 5 4 3 . 9 8}$ & $\mathbf{1}$ & $\mathbf{3 1 7 1 0 0}$
\end{tabular}




\section{Table 2}

Comparisons between the interface definition used in our analysis and alternative definitions. We looked at the subset of publicly traded software firms around the time of the three judicial decisions in the Lotus v. Borland case. We estimated an event study, where one observation was used for each firm and judicial decision. The dependent variable was the actual return of the firm in a window around the event. As dependent variables, we employ dummy variables denoting the 359 distinct technology classes into which the firms were sorted, as well as dummy variables for each observation date. The industry dummy variables are coded as one if the firm was assigned to that class based on the 1994 classification scheme when such scheme is recorded by Corptech or the classification scheme in the closest year to 1994. We then examine the coefficients on the technology classes based on the regressions. Panel A summarizes our scheme for defining strong, median and no response groups. Panel B indicates for each approach, including our $a$ priori classification, the number of firms assigned to the strong and medium groups. We also compare the distribution to that in the scheme we ultimately relied on for the base analysis: using the absolute returns and the window from two days before to two days after the decision.

\section{Panel A}

\begin{tabular}{|c|c|c|c|}
\hline Dependent variable & Strong & Median & No Response \\
\hline $\begin{array}{l}\text { Percentage changes in the stock } \\
\text { price }\end{array}$ & $\begin{array}{l}\text { Coefficient is negative and } \mathrm{p}- \\
\text { value }<.2\end{array}$ & $\begin{array}{l}\text { Coefficient is negative and } .2 \leq \mathrm{p} \text { - } \\
\text { value } \leq .8\end{array}$ & $\begin{array}{l}\text { All codes that are not classified } \\
\text { into strong or median group }\end{array}$ \\
\hline $\begin{array}{l}\text { Absolute percentage changes in } \\
\text { the stock price }\end{array}$ & $\begin{array}{l}\text { Coefficient is positive and } \mathrm{p} \text {-value } \\
<.2\end{array}$ & $\begin{array}{l}\text { Coefficient is positive and } .2 \leq \mathrm{p} \text { - } \\
\text { value } \leq .8\end{array}$ & $\begin{array}{l}\text { All codes that are not classified } \\
\text { into strong or median group }\end{array}$ \\
\hline
\end{tabular}

\footnotetext{
*** The ruling by the district court was in favor of Lotus. To be consistent, we negate the relative return during the first judicial decision in the pooled OLS regression. If we wish to identify the firms most adversely affected by the decisions, we should look at the ones who have the most persistently negative reaction.
} 


\section{Panel B}

\begin{tabular}{|c|c|c|c|c|}
\hline \multicolumn{5}{|c|}{ Event Window (t-1, t+1) } \\
\hline \multirow{2}{*}{ Dependent Variable } & \multicolumn{2}{|c|}{ Percentage Changes } & \multicolumn{2}{c|}{ Absolute Percentage Changes } \\
\cline { 2 - 5 } & $\begin{array}{c}\text { Strong / } \\
\text { Median }\end{array}$ & $\begin{array}{c}\text { No } \\
\text { Response }\end{array}$ & $\begin{array}{c}\text { Strong / } \\
\text { Median }\end{array}$ & No Response \\
\hline $\begin{array}{c}\text { Number of Codes } \\
\text { from regression } \\
\text { analysis }\end{array}$ & 91 & 268 & 91 & 268 \\
\hline $\begin{array}{c}\text { Number of Codes } \\
\text { included in our } \\
\text { selection }\end{array}$ & 35 & 51 & 55 & 31 \\
\hline Percentage Selected & .38 & .19 & .60 & .12 \\
\hline
\end{tabular}

\begin{tabular}{|c|c|c|c|c|}
\hline \multicolumn{5}{|c|}{ Event Window (t-2, t+2) } \\
\hline \multirow{2}{*}{ Dependent Variable } & \multicolumn{2}{|c|}{ Percentage Changes } & \multicolumn{2}{|c|}{ Absolute Percentage Changes } \\
\cline { 2 - 5 } & $\begin{array}{c}\text { Strong / } \\
\text { Median }\end{array}$ & $\begin{array}{c}\text { No } \\
\text { Response }\end{array}$ & $\begin{array}{c}\text { Strong / } \\
\text { Median }\end{array}$ & No Response \\
\hline $\begin{array}{c}\text { Number of Codes } \\
\text { from regression } \\
\text { analysis }\end{array}$ & 87 & 272 & 86 & 273 \\
\hline $\begin{array}{c}\text { Number of Codes } \\
\text { included in our } \\
\text { selection }\end{array}$ & 38 & 48 & 86 & 0 \\
\hline Percentage Selected & .44 & .18 & 1 & 0 \\
\hline
\end{tabular}

\begin{tabular}{|c|c|c|c|c|}
\hline \multicolumn{5}{|c|}{ Event Window (t-3, t+3) } \\
\hline \multirow{2}{*}{ Dependent Variable } & \multicolumn{2}{|c|}{ Percentage Changes } & \multicolumn{2}{c|}{ Absolute Percentage Changes } \\
\cline { 2 - 5 } & $\begin{array}{c}\text { Strong / } \\
\text { Median }\end{array}$ & $\begin{array}{c}\text { No } \\
\text { Response }\end{array}$ & $\begin{array}{c}\text { Strong / } \\
\text { Median }\end{array}$ & No Response \\
\hline $\begin{array}{c}\text { Number of Codes } \\
\text { from regression } \\
\text { analysis }\end{array}$ & 43 & 316 & 111 & 248 \\
\hline $\begin{array}{c}\text { Number of Codes } \\
\text { included in our } \\
\text { selection }\end{array}$ & 17 & 69 & 57 & 29 \\
\hline Percentage Selected & .40 & .22 & .51 & .11 \\
\hline
\end{tabular}

\begin{tabular}{|c|c|c|}
\hline \multicolumn{3}{|c|}{ Our a priori Classification } \\
\hline $\begin{array}{c}\text { Number of Codes from our a } \\
\text { priori scheme }\end{array}$ & Strong / Median & No Response \\
\hline $\begin{array}{c}\text { Number of Codes included } \\
\text { in our selection }\end{array}$ & 51 & 308 \\
\hline Percentage Selected & .31 & 70 \\
\hline
\end{tabular}




\section{Table 3}

Summary statistics for variables we use to measure firms' performance. We use a number of ways to measure firms' performance such as percentage growth in sales, total assets, market capitalization, the number of employees, sales per employee, R\&D expenditure and the number of product lines. In Panel A to G, we report the means, medians, standard deviations of these measures for interface firms and non-interface firms respectively. An asterisk after a year number indicates that the value of interface firms is significantly greater than that of non-interface firms in that year with 90 percent confidence level by a one-tail t-test.

\begin{tabular}{|c|c|c|c|c|c|c|}
\hline \multicolumn{7}{|c|}{ Panel A: Growth in Sales } \\
\hline \multirow{2}{*}{ Year } & \multicolumn{3}{|c|}{ Interface Firms } & \multicolumn{3}{c|}{ Non-interface Firms } \\
\cline { 2 - 7 } & Mean & Median & Std. Dev. & Mean & Median & Std. Dev. \\
\hline 1990 & 2.49 & -0.37 & 8.40 & 0.81 & -0.67 & 3.23 \\
\hline 1992 & 0.69 & -0.03 & 7.25 & 2.14 & -0.03 & 23.81 \\
\hline 1994 & 0.67 & -0.06 & 7.80 & 0.29 & -0.06 & 1.58 \\
\hline $1996^{*}$ & 1.03 & -0.06 & 10.49 & 0.40 & -0.06 & 1.43 \\
\hline $1998^{*}$ & 1.43 & -0.08 & 13.45 & 0.49 & -0.08 & 3.24 \\
\hline 2000 & 0.59 & -0.08 & 6.37 & 0.68 & -0.08 & 8.40 \\
\hline
\end{tabular}

\begin{tabular}{|c|c|c|c|c|c|c|}
\hline \multicolumn{7}{|c|}{ Panel B: Growth in Total Asset } \\
\hline \multirow{2}{*}{ Year } & \multicolumn{3}{|c|}{ Interface Firms } & \multicolumn{3}{c|}{ Non-interface Firms } \\
\cline { 2 - 7 } & Mean & Median & Std. Dev. & Mean & Median & Std. Dev. \\
\hline 1990 & & & & & & \\
\hline 1992 & 0.33 & 0.05 & 0.85 & 0.44 & 0.10 & 0.87 \\
\hline 1994 & 0.74 & 0.16 & 3.37 & 0.59 & 0.15 & 1.54 \\
\hline 1996 & 1.70 & 0.25 & 9.91 & 0.99 & 0.29 & 2.96 \\
\hline 1998 & 1.11 & 0.16 & 7.23 & 0.61 & 0.16 & 1.54 \\
\hline 2000 & 2.76 & 0.04 & 14.28 & 1.81 & 0.17 & 9.31 \\
\hline
\end{tabular}

\begin{tabular}{|c|c|c|c|c|c|c|}
\hline \multicolumn{7}{|c|}{ Panel C: Growth in Market Capitalization } \\
\hline \multirow{2}{*}{ Year } & \multicolumn{3}{|c|}{ Interface Firms } & \multicolumn{3}{c|}{ Non-interface Firms } \\
\cline { 2 - 7 } & Mean & Median & Std. Dev. & Mean & Median & Std. Dev. \\
\hline 1990 & & & & & & \\
\hline 1992 & 0.86 & 0.14 & 2.23 & 1.53 & 0.44 & 3.15 \\
\hline 1994 & 0.48 & 0.11 & 1.37 & 0.42 & 0.19 & 0.88 \\
\hline 1996 & 2.05 & 0.41 & 8.80 & 1.07 & 0.55 & 2.03 \\
\hline 1998 & 1.60 & 0.00 & 19.31 & 0.39 & 0.00 & 1.28 \\
\hline 2000 & 1.33 & 0.00 & 8.97 & 2.23 & 0.00 & 25.71 \\
\hline
\end{tabular}

\begin{tabular}{|c|c|c|c|c|c|c|}
\hline \multicolumn{7}{|c|}{ Panel D: Growth in Number of Employees } \\
\hline \multirow{2}{*}{ Year } & \multicolumn{3}{|c|}{ Interface Firms } & \multicolumn{3}{c|}{ Non-interface Firms } \\
\cline { 2 - 7 } & Mean & Median & Std. Dev. & Mean & Median & Std. Dev. \\
\hline 1990 & 0.67 & -0.25 & 3.63 & 0.50 & -0.53 & 2.34 \\
\hline 1992 & 0.42 & 0.00 & 3.86 & 0.18 & 0.00 & 0.61 \\
\hline 1994 & 0.50 & 0.00 & 7.17 & 0.36 & 0.00 & 2.00 \\
\hline $1996^{*}$ & 0.59 & 0.00 & 5.10 & 0.25 & 0.00 & 0.96 \\
\hline 1998 & 0.56 & 0.00 & 6.62 & 0.62 & 0.00 & 6.49 \\
\hline 2000 & 0.52 & 0.00 & 4.70 & 0.66 & 0.00 & 8.64 \\
\hline
\end{tabular}




\begin{tabular}{|c|c|c|c|c|c|c|}
\hline \multicolumn{7}{|c|}{ Panel E: Growth in Sales Per Employee } \\
\hline \multirow{2}{*}{ Year } & \multicolumn{3}{|c|}{ Interface Firms } & \multicolumn{3}{c|}{ Non-interface Firms } \\
\cline { 2 - 7 } & Mean & Median & Std. Dev. & Mean & Median & Std. Dev. \\
\hline 1990 & 0.29 & 0.26 & 0.54 & 1.59 & -0.03 & 3.23 \\
\hline 1992 & 0.25 & -0.03 & 1.75 & 0.36 & -0.03 & 1.22 \\
\hline $1994^{*}$ & 0.40 & -0.06 & 3.11 & 0.14 & -0.06 & 1.07 \\
\hline 1996 & 0.26 & -0.06 & 1.87 & 0.25 & -0.06 & 1.36 \\
\hline 1998 & 0.33 & -0.08 & 4.04 & 0.15 & -0.08 & 1.44 \\
\hline 2000 & -0.01 & -0.13 & 0.77 & -0.06 & -0.16 & 0.66 \\
\hline
\end{tabular}

\begin{tabular}{|c|c|c|c|c|c|c|}
\hline \multicolumn{7}{|c|}{ Panel F: Growth in R\&D Expenditure } \\
\hline \multirow{2}{*}{ Year } & \multicolumn{3}{|c|}{ Interface Firms } & \multicolumn{3}{c|}{ Non-interface Firms } \\
\cline { 2 - 7 } & Mean & Median & Std. Dev. & Mean & Median & Std. Dev. \\
\hline $1990^{*}$ & 0.34 & 0.34 & 0.46 & 0.20 & 0.15 & 0.34 \\
\hline 1992 & 0.48 & 0.10 & 2.47 & 0.34 & 0.18 & 0.73 \\
\hline 1994 & 0.33 & 0.17 & 0.63 & 0.49 & 0.15 & 1.47 \\
\hline 1996 & 0.72 & 0.26 & 2.14 & 0.58 & 0.29 & 1.09 \\
\hline 1998 & 0.38 & 0.15 & 1.35 & 0.32 & 0.12 & 0.80 \\
\hline 2000 & 0.57 & 0.19 & 2.12 & 0.66 & 0.23 & 1.32 \\
\hline
\end{tabular}

\begin{tabular}{|c|c|c|c|c|c|c|}
\hline \multicolumn{9}{|c|}{ Panel G: Growth in the Number of Product Lines } \\
\hline \multirow{2}{*}{ Year } & \multicolumn{3}{|c|}{ Interface Firms } & \multicolumn{3}{c|}{ Non-interface Firms } \\
\cline { 2 - 7 } & Mean & Median & Std. Dev. & Mean & Median & Std. Dev. \\
\hline $1990^{*}$ & 1.81 & 0.33 & 6.28 & -0.35 & -0.46 & 0.47 \\
\hline $1992^{*}$ & 0.54 & 0.00 & 1.46 & 0.10 & 0.00 & 0.59 \\
\hline $1994 *$ & 0.19 & 0.00 & 1.02 & 0.01 & 0.00 & 0.43 \\
\hline $1996^{*}$ & 0.28 & 0.00 & 1.34 & 0.01 & 0.00 & 0.40 \\
\hline $1998^{*}$ & 0.23 & 0.00 & 1.03 & 0.00 & 0.00 & 0.35 \\
\hline $2000^{*}$ & 0.18 & 0.00 & 1.07 & -0.01 & 0.00 & 0.35 \\
\hline
\end{tabular}




\section{Table 4}

Regression analysis of the patenting behaviors of interface firms before and after the Lotus v. Borland lawsuit. The sample consists of biannual observations of 15,207 software firms between 1992 and 1998. We use a number of specifications including OLS, negative binomial and Poisson. The first row indicates the particular type of specification used. The number of patents filed each year is used as the dependent variable in all regressions. Entry rate is defined as the percentage of new entries in a technology class and is used to control for industry competition. Lagged total number of patents applied is the total number of patents filed by a firm in the past and is used as a way to include fixed effects in the regressions. Heteroskedasticadjusted standard errors in parentheses. ${ }^{10}$

\begin{tabular}{|c|c|c|c|c|c|c|c|}
\hline & Poisson & Poisson & Poisson & OLS & $\begin{array}{l}\text { Negative } \\
\text { Binomial }\end{array}$ & $\begin{array}{l}\text { Negative } \\
\text { Binomial }\end{array}$ & $\begin{array}{l}\text { Negative } \\
\text { Binomial }\end{array}$ \\
\hline \multirow{2}{*}{ interface } & -1.069 & -.991 & -1.119 & -.023 & .124 & -.752 & -.714 \\
\hline & {$[.034] * * *$} & {$[.033] * * *$} & {$[.034]^{* * *}$} & {$[.010]^{* *}$} & {$[.794]$} & {$[.389]^{*}$} & {$[.403]^{*}$} \\
\hline \multirow{2}{*}{$\begin{array}{c}\text { interface } * \\
\text { year } 1996\end{array}$} & 3.869 & 2.329 & 2.712 & .029 & 3.917 & .981 & 1.006 \\
\hline & {$[.075]^{* * *}$} & {$[.078]^{* * *}$} & {$[.082] * * *$} & {$[.015]^{* *}$} & {$[.960]^{* * *}$} & {$[.551]^{*}$} & {$[.562]^{*}$} \\
\hline \multirow{2}{*}{$\begin{array}{c}\text { interface } * \\
\text { year } 1998\end{array}$} & 2.148 & 1.505 & 1.695 & .031 & 1.134 & 1.329 & 1.221 \\
\hline & {$[.055]^{* * *}$} & {$[.049] * * *$} & {$[.051]^{* * *}$} & {$[.014] * *$} & {$[1.032]$} & {$[.565]^{* *}$} & {$[.580]^{* *}$} \\
\hline \multirow{2}{*}{ Year 1994} & -1.546 & -1.508 & -1.494 & .002 & -2.393 & .591 & .837 \\
\hline & {$[.039] * * *$} & {$[.039]^{* * *}$} & {$[.040]^{* * *}$} & [.009] & {$[[.624] * * *$} & {$[.373]$} & {$[.393] * *$} \\
\hline \multirow{2}{*}{ Year 1996} & -2.484 & -2.559 & -2.850 & -.010 & -3.184 & .783 & .794 \\
\hline & {$[.071] * * *$} & {$[.070]^{* * *}$} & {$[.074] * * *$} & {$[.014]$} & {$[.784] * * *$} & [.499] & {$[.516]$} \\
\hline \multirow{2}{*}{ Year 1998} & -1.860 & -1.194 & -1.199 & -.013 & -1.690 & -.174 & .248 \\
\hline & {$[.049] * * *$} & {$[.041]^{* * *}$} & {$[.045]^{* * *}$} & [.013] & {$[.837]^{* *}$} & [.512] & [.546] \\
\hline \multirow{2}{*}{$\begin{array}{l}\text { Age of the } \\
\text { firm }\end{array}$} & -.021 & .011 & .007 & .001 & -.000 & -.022 & -.016 \\
\hline & {$[.001] * * *$} & {$[.001] * * *$} & {$[.001]^{* * *}$} & {$[.000]^{* *}$} & {$[.010]$} & {$[.010]^{* *}$} & {$[.010]$} \\
\hline \multirow{2}{*}{$\begin{array}{l}\text { Lagged } \\
\text { value of } \\
\text { sales }\end{array}$} & .076 & .050 & .060 & .023 & 4.501 & 3.176 & 3.381 \\
\hline & {$[.001]^{* * *}$} & {$[.001]^{* * *}$} & {$[.001]^{* * * *}$} & {$[.001]^{* * *}$} & {$[1.351]^{* * *}$} & {$[.548]^{* * *}$} & {$[.569]^{* * *}$} \\
\hline \multirow{2}{*}{$\begin{array}{l}\text { Lagged total } \\
\text { number of } \\
\text { patents } \\
\text { applied }\end{array}$} & & .002 & .002 & .003 & & .078 & .076 \\
\hline & & {$[.000]^{* * *}$} & {$[.000]^{* * *}$} & {$[.000] * * *$} & & {$[.022]^{* * *}$} & {$[.021]^{* * *}$} \\
\hline \multirow{2}{*}{ Entry rate } & -1.324 & & 1.392 & .036 & .639 & & 2.914 \\
\hline & {$[.090]^{*} * *$} & & {$[.097] * * *$} & {$[.030]$} & [2.161] & & {$[1.425]^{* *}$} \\
\hline Observations & 12085 & 12122 & 12085 & 12085 & 12085 & 12122 & 12085 \\
\hline$R$-squared & 0.09 & 0.52 & 0.52 & .40 & 0.02 & 0.12 & 0.13 \\
\hline
\end{tabular}

* significant at $10 \% ; * *$ significant at $5 \%$;*** significant at $1 \%$

\footnotetext{
${ }^{10} \mathrm{We}$ also run several panel regressions employing within (or fixed effects), between and random effects specifications. The coefficients of the interaction terms, (interface * year 1996) and (interface * year 1998), are both positive in these regressions. However, their p-values are around 0.2.
} 


\section{Table 5}

Regression analysis of the impact of the change of patenting behaviors on firms' financial performance. The sample consists of biannual observations of 15,207 software firms between 1992 and 1998. We present the results in three panels, using various dependent variables. The first row of each table indicates the performance measures we use as dependent variables. For each measure, we first run the regressions without using the predicted number of patents. This examines whether firms in sectors with more generous patent policies grow more rapidly, regardless of their specific patenting activity. Then we add the lagged predicted number of patents and its interaction with interface and year dummies to examine to what extent the difference in their patenting activity affects their performance. All regressions employ an ordinary least squares specification except in the case of the inception of venture financing where we employ a probit specification. Heteroskedastic-adjusted standard errors in parentheses.

Panel A

\begin{tabular}{|c|c|c|c|c|}
\hline & Sales Growth & Sales Growth & $\begin{array}{c}\text { Total Asset } \\
\text { Growth }\end{array}$ & $\begin{array}{c}\text { Total Asset } \\
\text { Growth }\end{array}$ \\
\hline \multirow{2}{*}{ Year 1994} & -0.593 & 0.071 & -13.864 & -25.743 \\
\hline & {$[1.166]$} & {$[1.002]$} & [16.368] & {$[30.151]$} \\
\hline \multirow{2}{*}{ Year 1996} & 7.714 & 5.334 & -0.973 & -2.932 \\
\hline & {$[2.065]^{* * *}$} & {$[1.756]^{* * *}$} & [27.365] & [54.078] \\
\hline \multirow{2}{*}{ Year 1998} & -0.754 & -0.470 & -5.007 & -10.347 \\
\hline & [2.071] & {$[1.732]$} & [22.638] & [44.855] \\
\hline \multirow{2}{*}{ interface } & -0.126 & 0.462 & 14.912 & 26.857 \\
\hline & [1.196] & {$[1.073]$} & [14.561] & [29.682] \\
\hline \multirow{2}{*}{ interface * year1996 } & -7.685 & -6.920 & -14.316 & -25.072 \\
\hline & {$[2.389]^{* * *}$} & {$[2.251]^{* * *}$} & [31.550] & [60.372] \\
\hline \multirow{2}{*}{ interface * year1998 } & 1.598 & -24.090 & -11.683 & -22.735 \\
\hline & {$[2.413]$} & {$[2.905]^{* * *}$} & [26.533] & {$[53.224]$} \\
\hline \multirow{2}{*}{ Age of the firm } & 0.103 & 0.105 & 0.175 & 0.540 \\
\hline & {$[0.044]^{* *}$} & {$[0.039]^{* * *}$} & [0.293] & {$[0.684]$} \\
\hline \multirow{2}{*}{ Entry rate } & 1.813 & -7.882 & -28.524 & -63.675 \\
\hline & [4.496] & {$[4.096]^{*}$} & [51.740] & [105.794] \\
\hline \multirow{2}{*}{$\begin{array}{l}\text { Lagged predicted number } \\
\text { of patents }\end{array}$} & & 0.000 & & 0.000 \\
\hline & & {$[0.000]$} & & {$[0.000]$} \\
\hline \multirow{2}{*}{$\begin{array}{l}\text { interface } * \text { year } 1996 * \\
\text { lagged predicted number of } \\
\text { patents }\end{array}$} & & 12.274 & & -0.004 \\
\hline & & {$[5.032]^{* *}$} & & {$[0.075]$} \\
\hline \multirow{2}{*}{$\begin{array}{l}\text { interface * year1998* } \\
\text { lagged predicted number of } \\
\text { patents }\end{array}$} & & 36.551 & & 0.852 \\
\hline & & {$[2.953]^{* * *}$} & & [15.865] \\
\hline \multirow{2}{*}{ Lagged total asset } & & & -0.058 & -0.078 \\
\hline & & & [0.185] & [0.381] \\
\hline \multirow{2}{*}{ Lagged value of sales } & -0.119 & -0.119 & & \\
\hline & {$[0.234]$} & {$[0.174]$} & & \\
\hline Observations & 12473 & 7108 & 2372 & 1262 \\
\hline$R$-squared & 0.00 & 0.03 & 0.00 & 0.01 \\
\hline
\end{tabular}


Panel B

\begin{tabular}{|c|c|c|c|c|c|c|}
\hline & $\begin{array}{l}\text { Market Cap } \\
\text { Growth }\end{array}$ & $\begin{array}{l}\text { Market Cap } \\
\text { Growth }\end{array}$ & $\begin{array}{l}\text { Employees } \\
\text { Growth }\end{array}$ & $\begin{array}{l}\text { Employees } \\
\text { Growth }\end{array}$ & $\begin{array}{c}\text { Sales per } \\
\text { employee } \\
\text { Growth }\end{array}$ & $\begin{array}{l}\text { Sales per } \\
\text { employee } \\
\text { Growth }\end{array}$ \\
\hline \multirow{2}{*}{ Year 1994} & -1.116 & -1.627 & 0.075 & 0.036 & -0.488 & 0.312 \\
\hline & [0.967] & {$[1.686]$} & [0.407] & {$[0.242]$} & {$[1.033]$} & {$[0.162]^{*}$} \\
\hline \multirow{2}{*}{ Year 1996} & -0.761 & -1.926 & 0.030 & -0.136 & 2.325 & 0.380 \\
\hline & [1.617] & {$[3.058]$} & {$[0.652]$} & [0.389] & {$[1.754]$} & {$[0.272]$} \\
\hline \multirow{2}{*}{ Year 1998} & -1.701 & -3.397 & 1.655 & 0.153 & 0.115 & 0.230 \\
\hline & {$[1.300]$} & [2.449] & {$[0.597]^{* * *}$} & {$[0.357]$} & [1.619] & {$[0.252]$} \\
\hline \multirow{2}{*}{ interface } & -0.632 & -1.880 & 0.154 & 0.203 & 0.842 & 0.096 \\
\hline & [0.842] & {$[1.608]$} & {$[0.415]$} & {$[0.258]$} & [0.993] & {$[0.162]$} \\
\hline \multirow{2}{*}{ interface * year 1996} & 1.534 & 2.564 & 0.198 & -1.427 & -3.133 & -0.225 \\
\hline & {$[1.866]$} & [3.408] & {$[0.751]$} & {$[0.496] * * *$} & [2.023] & {$[0.350]$} \\
\hline \multirow{2}{*}{ interface * year 1998} & 1.870 & -1.317 & -1.478 & -1.203 & -0.540 & -0.531 \\
\hline & [1.524] & [2.900] & {$[0.683]^{* *}$} & {$[0.709]^{*}$} & {$[1.886]$} & {$[0.528]$} \\
\hline \multirow{2}{*}{ Age of the firm } & -0.011 & -0.038 & -0.005 & -0.011 & -0.037 & -0.004 \\
\hline & {$[0.016]$} & {$[0.036]$} & {$[0.015]$} & {$[0.008]$} & {$[0.036]$} & {$[0.006]$} \\
\hline \multirow{2}{*}{ Entry rate } & -1.882 & -5.880 & -1.365 & 0.187 & 1.405 & (dropped) \\
\hline & {$[3.003]$} & [5.654] & [1.467] & [0.924] & [3.753] & \\
\hline \multirow{2}{*}{$\begin{array}{l}\text { Lagged predicted } \\
\text { number of patents }\end{array}$} & & 0.000 & & 0.030 & & 0.000 \\
\hline & & {$[0.000]$} & & [0.039] & & {$[0.000]$} \\
\hline \multirow{2}{*}{$\begin{array}{c}\text { interface } * \text { year } 1996 \\
* \text { lagged predicted } \\
\text { number of patents }\end{array}$} & & 0.001 & & 7.587 & & 0.651 \\
\hline & & {$[0.004]$} & & {$[1.085]^{* * *}$} & & {$[0.762]$} \\
\hline \multirow{2}{*}{$\begin{array}{c}\text { interface * year1998 } \\
* \text { lagged predicted } \\
\text { number of patents }\end{array}$} & & 5.580 & & 1.846 & & 1.377 \\
\hline & & {$[0.836]^{* * *}$} & & {$[0.826]^{* *}$} & & {$[0.623]^{* *}$} \\
\hline \multirow{2}{*}{$\begin{array}{c}\text { Lagged sales per } \\
\text { employee }\end{array}$} & & & & & -0.030 & -0.012 \\
\hline & & & & & {$[0.145]$} & {$[0.017]$} \\
\hline \multirow{2}{*}{$\begin{array}{l}\text { Lagged number of } \\
\text { employees }\end{array}$} & & & 0.000 & 0.000 & & \\
\hline & & & {$[0.000]^{* * *}$} & {$[0.000] * * *$} & & \\
\hline \multirow{2}{*}{ Lagged market cap } & -0.009 & -0.034 & & & & \\
\hline & {$[0.010]$} & {$[0.018]^{*}$} & & & & \\
\hline Observations & 2080 & 1124 & 11031 & 6653 & 9341 & 5530 \\
\hline$R$-squared & 0.00 & 0.04 & 0.00 & 0.01 & 0.00 & 0.01 \\
\hline
\end{tabular}


Panel C

\begin{tabular}{|c|c|c|c|c|c|c|}
\hline & $\begin{array}{l}\text { R\&D } \\
\text { Growth }\end{array}$ & $\begin{array}{l}\text { R\&D } \\
\text { Growth }\end{array}$ & $\begin{array}{l}\text { Product } \\
\text { Line } \\
\text { Growth }\end{array}$ & $\begin{array}{l}\text { Product } \\
\text { Line } \\
\text { Growth }\end{array}$ & $\begin{array}{l}\text { Get First } \\
\text { Round } \\
\text { Finance }\end{array}$ & $\begin{array}{l}\text { Get First } \\
\text { Round } \\
\text { Finance }\end{array}$ \\
\hline \multirow{2}{*}{ Year 1994} & -0.169 & 0.162 & -0.038 & 0.016 & 0.091 & 0.347 \\
\hline & {$[0.112]$} & {$[0.108]$} & {$[0.018]^{* *}$} & {$[0.026]$} & [0.102] & {$[0.191]^{*}$} \\
\hline \multirow{2}{*}{ Year 1996} & -0.028 & 0.003 & -0.014 & 0.018 & 0.102 & 0.372 \\
\hline & {$[0.166]$} & {$[0.182]$} & [0.029] & {$[0.044]$} & {$[0.146]$} & {$[0.268]$} \\
\hline \multirow{2}{*}{ Year 1998} & -0.267 & -0.177 & -0.020 & 0.019 & 0.368 & 0.544 \\
\hline & {$[0.146]^{*}$} & {$[0.161]$} & {$[0.026]$} & [0.039] & {$[0.124]^{* * *}$} & {$[0.274] * *$} \\
\hline \multirow{2}{*}{ interface } & -0.066 & -0.141 & 0.396 & 0.372 & 0.014 & -0.056 \\
\hline & {$[0.092]$} & {$[0.104]$} & {$[0.018]^{* * *}$} & {$[0.028]^{* * *}$} & {$[0.096]$} & {$[0.206]$} \\
\hline \multirow{2}{*}{ interface * year 1996} & 0.182 & 0.433 & 0.025 & -0.003 & 0.041 & -0.040 \\
\hline & {$[0.197]$} & {$[0.206]^{* *}$} & {$[0.035]$} & {$[0.050]$} & {$[0.175]$} & {$[0.296]$} \\
\hline \multirow{2}{*}{ interface * year 1998} & 0.091 & 0.258 & -0.028 & -0.024 & 0.060 & 0.189 \\
\hline & {$[0.172]$} & {$[0.191]$} & {$[0.031]$} & {$[0.054]$} & [0.145] & {$[0.335]$} \\
\hline \multirow{2}{*}{ Age of the firm } & -0.009 & -0.006 & 0.002 & 0.002 & -0.028 & -0.012 \\
\hline & {$[0.002]^{* * *}$} & {$[0.003]^{* *}$} & {$[0.001] * * *$} & {$[0.001]^{* *}$} & {$[0.005]^{* * *}$} & {$[0.008]$} \\
\hline \multirow{2}{*}{ Entry rate } & 0.244 & -0.298 & 0.065 & 0.207 & 0.434 & 2.064 \\
\hline & {$[0.311]$} & {$[0.387]$} & {$[0.063]$} & {$[0.100]^{* *}$} & {$[0.258]^{*}$} & {$[0.577]^{* * *}$} \\
\hline \multirow{2}{*}{$\begin{array}{l}\text { Lagged predicted } \\
\text { number of patents }\end{array}$} & & 0.000 & & 0.000 & & 0.000 \\
\hline & & {$[0.000]$} & & {$[0.000]^{* *}$} & & {$[0.000]$} \\
\hline \multirow{2}{*}{$\begin{array}{c}\text { interface } * \text { year } 1996 \\
* \text { lagged predicted } \\
\text { number of patents }\end{array}$} & & 0.000 & & 0.003 & & 0.000 \\
\hline & & {$[0.000]$} & & {$[0.000]^{* * *}$} & & {$[0.010]$} \\
\hline \multirow{2}{*}{$\begin{array}{c}\text { interface } * \text { year } 1998 \\
* \text { lagged predicted } \\
\text { number of patents }\end{array}$} & & -0.009 & & 0.017 & & -0.006 \\
\hline & & [0.052] & & [0.041] & & [0.249] \\
\hline \multirow{2}{*}{$\begin{array}{l}\text { Lagged number of } \\
\text { product lines }\end{array}$} & & & -0.049 & -0.045 & & \\
\hline & & & {$[0.002]^{* * *}$} & {$[0.002] * * *$} & & \\
\hline \multirow{2}{*}{ Lagged R\&D } & 0.000 & 0.000 & & & & \\
\hline & {$[0.000]^{* * *}$} & {$[0.000]^{*}$} & & & & \\
\hline Observations & 2580 & 1032 & 25707 & 12245 & 31792 & 11439 \\
\hline$R$-squared & 0.02 & 0.03 & 0.05 & 0.07 & 0.04 & 0.05 \\
\hline
\end{tabular}

* significant at $10 \%$; * significant at 5\%; *** significant at $1 \%$ 


\section{Table 6}

Robustness checks using other definitions for interface firms. The sample consists of biannual observations of 15,207 software firms between 1992 and 1998. As a robustness check, we use different event windows and relative or absolute returns for identifying affected firms. Then we repeat the regressions in Table 4 using these new definitions and report results here. In all cases, results from the Poisson specification are reported. Heteroskedastic-adjusted standard errors in parentheses.

We report the regression results based on the following three interface definitions:

A. We use $(t-2, t+2)$ as the event window and use the absolute return as the dependent variable for identifying affected firms. Here we only consider firms whose technology class(es) belong to the strongly affected class as the interface firms.

B. We use $(t-2, t+2)$ as the event window and use the relative return as the dependent variable for identifying affected firms. Here we consider firms whose technology class(es) belong to the strong or median class as the interface firms.

C. We use $(t-3, t+3)$ as the event window and use the absolute return as the dependent variable for identifying affected firms. Here we consider firms whose technology class(es) belong to the strong or median class as the interface firms.

\begin{tabular}{|c|c|c|c|}
\hline Regression ID & $\mathbf{A}$ & B & $C$ \\
\hline \multirow[t]{2}{*}{ interface } & -0.206 & -0.020 & -0.131 \\
\hline & {$[0.042] * * *$} & [0.042] & {$[0.037] * * *$} \\
\hline \multirow[t]{2}{*}{ Interface * year1996 } & 1.942 & 3.179 & 1.849 \\
\hline & {$[0.063]^{* * *}$} & {$[0.142]^{* * *}$} & {$[0.082]^{* * *}$} \\
\hline \multirow[t]{2}{*}{ Interface * year1998 } & 1.553 & 0.971 & 1.392 \\
\hline & {$[0.052]^{* * *}$} & {$[0.059]^{* * *}$} & {$[0.058]^{* * *}$} \\
\hline \multirow[t]{2}{*}{ Year 1994} & -1.519 & -1.552 & -1.505 \\
\hline & {$[0.040]^{* * *}$} & {$[0.041]^{* * *}$} & {$[0.041] * * *$} \\
\hline \multirow[t]{2}{*}{ Year 1996} & -1.642 & -3.651 & -2.343 \\
\hline & {$[0.041] * * *$} & {$[0.139] * * *$} & {$[0.076] * * *$} \\
\hline \multirow[t]{2}{*}{ Year 1998} & -0.619 & -0.790 & -1.104 \\
\hline & {$[0.032]^{* * *}$} & {$[0.056]^{* * *}$} & {$[0.054]^{* * *}$} \\
\hline \multirow[t]{2}{*}{ Age of the firm } & 0.003 & 0.005 & 0.005 \\
\hline & {$[0.001]^{* * *}$} & {$[0.001]^{* * *}$} & {$[0.001]^{* * *}$} \\
\hline \multirow[t]{2}{*}{ Lagged value of sales } & 0.000 & 0.000 & 0.000 \\
\hline & {$[0.000]^{* * *}$} & {$[0.000]^{* * *}$} & {$[0.000]^{* * *}$} \\
\hline \multirow{2}{*}{$\begin{array}{l}\text { Lagged total number of patents } \\
\text { applied }\end{array}$} & 0.002 & 0.002 & 0.002 \\
\hline & {$[0.000]^{* * *}$} & {$[0.000]^{* * *}$} & {$[0.000]^{* * *}$} \\
\hline \multirow[t]{2}{*}{ Entry rate } & 1.189 & 1.734 & 1.802 \\
\hline & {$[0.105]^{* * *}$} & {$[0.105]^{* * * *}$} & {$[0.103] * * *$} \\
\hline Observations & 12085 & 12085 & 12085 \\
\hline$R$-squared & .53 & .52 & .52 \\
\hline
\end{tabular}

$*$ significant at $10 \% ; * *$ significant at $5 \%$; *** significant at $1 \%$ 